Jurnal Health Sains: p-ISSN: 2723-4339 e-ISSN: 2548-1398

Vol. 2, No. 3, Maret 2021

\title{
FAKTOR-FAKTOR YANG MEMENGARUHI GANGGUAN FUNGSI PARU PADA PETUGAS PARKIR DI KOTA MEDAN
}

\section{Novika Haryanti Purba, Nurmaini dan Irnawati Marsaulina}

Universitas Sumatera Utara (USU) Medan Sumatera Utara, Indonesia

Email: novikaharyantipurbag@gmail.com,nurmainik@yahoo.com dan irnamarsa@yahoo.com

\begin{tabular}{l}
\hline ARTIKEL INFO \\
\hline Tanggal diterima: 5 Maret 2021 \\
Tanggal direvisi: 15 Maret 2021 \\
Tanggal disetujui: 25 Maret \\
2021 \\
\hline
\end{tabular}

ABSTRACT

Keywords:

parking attendants; pulmonary

function; personal protective

equipment (PPE)

Human life is very dependent on the environment as well as air for breathing, clean water for drinking, as well as daily and other necessities. Air is one of the components of the environment, so its quality must be maintained, in the air containing all the large amounts of oxygen is the most important component for the development of human life. Living things without air for just two minutes will not be able to survive. The purpose of this study is to analyze the factors that affect lung function disorders in parking attendants in Medan city. Methods this type of research is an analytic observational study with a cross sectional design. The research population was 30 parking attendants in the city of Medan. The sample of this research is all parking attendants in Medan City. Results as many as $60 \%$ of workers had lung function problems and as many as $40 \%$ had no lung function problems, based on the analysis showed that there was a relationship between age $(p=0.001)$, years of service $(p$ $=0.011)$, and PPE $(p=0.010)$ with lung function disorders on parking attendants in Medan City. Conclusion age, years of work, and use of PPE can cause lung function problems in Medan City.

\section{ABSTRAK}

Hidup manusia sangat bergantung dari lingkungannya seperti halnya udara buat pernapasan, air bersih buat minum, serta keperluan sehari-hari dan lainnya. Udara salah satu komponen lingkungan, sehingga kualitasnya mesti terjaga, di udara mengandung seluruh besar oksigen merupakan komponen terpenting untuk perkembangan hidup manusia. Makhluk hidup tanpa udara selama dua menit saja tidak akan dapat bertahan hidup.Tujuan penelitian ini untuk menganalisis faktor-faktor yang memengaruhi gangguan fungsi paru pada petugas parkir di kota medan. Jenis penelitian ini adalah penelitian observasional analitik dengan desain cross sectional. Populasi penelitan sebanyak 30 orang petugas parkir di kota Medan. Sampel penelitian ini adalah seluruh petugas parkir di Kota Medan. Hasil sebanyak 60\% pekerja mengalami gangguan fungsi paru dan sebanyak $40 \%$ tidak mengalami gangguan fungsi paru, berdasarkan 
Kata Kunci:

petugas parkir; fungsi paru; alat pelindung diri (APD) analisis menunjukkan ada hubungan antara umur ( $\mathrm{p}=$ $0,001)$, masa kerja $(\mathrm{p}=0,011)$, dan APD $(\mathrm{p}=0,010)$ dengan gangguan fungsi paru pada petugas parkir di Kota Medan. Kesimpulan umur, masa kerja, dan penggunaan APD dapat menyebabkan gangguan fungsi paru di Kota Medan.

\section{Pendahuluan}

Hidup manusia sangat bergantung dari lingkungannya seperti halnya udara buat pernapasan, air bersih buat minum, serta keperluan sehari-hari dan lainnya (Sumampouw, 2019). Udara salah satu komponen lingkungan, sehingga kualitasnya mesti terjaga, di udara mengandung seluruh besar oksigen merupakan komponen terpenting untuk perkembangan hidup manusia. Makhluk hidup tanpa udara selama dua menit saja tidak akan dapat bertahan hidup (Mukono, H. 2018).

Udara terdiri dari tiga unsur utama, yaitu udara kering, uap air, dan aerosol. Kandungan udara kering adalah 78 persen Nitrogen, 20 persen Oksigen, 0,93 persen

Argon, 0,03 persen Karbon Dioksida, 0,003 persen gas-gas lain (Neon, Helium, Metana, Kripton, Hidrogen, Xenon, Ozon, Radon) (Pratomo, 2019). Gas oksigen salah satu pendukung untuk kelangsungan hidup manusia, hewan dan tumbuhan. Keadaan tersebut dibilang sebagai udara yang sebagaimana mestinya (Purba, 2020).

Pencemaran udara bisa dimunculkan dari beberapa sumber alami maupun pekerjaan makhluk hidup. Pencemaran udara bisa terjadi kapanpun dan dimanapun, contohnya di rumah, kantor maupun di sekolah. Pencemaran ini seringkali dikatakan pencemaran dalam ruangan (indoor pollution). Sementara itu pencemaran di luar ruangan (outdoorpollution) dari gas
Coresponden Author:

Email: novikaharyantipurbag@gmail.com Artikel dengan akses terbuka dibawah lisensi

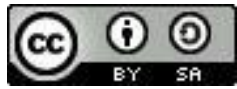

kendaraan bermotor, pekerjaan industry, proyek pekerjaan jalan tol, (Qadri et al., 2020). Beberapa pabrik dan pekerjaan oleh manusia. Salah satu bahan pencemar udara adalah TSP yaitu sejumlah debu berukuran 0,1 sampai $100 \mu \mathrm{m}$. Partikel udara di bentuk padat yang berukuran kurang dari $10 \mu \mathrm{m}$ dikatakan dengan PM10 (particulatematter) dan kurang dari $2,5 \mu \mathrm{m}$ di dalam rumah (PM2,5) dipercayai bagi pakar lingkungan dan kesehatan masyarakat dampak terjadinya timbulnya ISPA, sebab jumlah partikel padat PM10 dan PM2,5 bisa tinggal di saluran pernafasan dekat alveoli dan bronki (Sinolungan, 2009). Partikel debu yang berukuran kurang dari $10 \mu \mathrm{m}$ (PM10) sangat perlu diperhatikan, dikarenakan dapat menjadi hal lebih besar untuk dapat sampai ke daerah bagian dalam paru. Rambut di dalam hidung dapat menyaring debuyang berukuran lebih besar dari $10 \mu \mathrm{m}$. PM10 diprediksi ada antara 50 dan 60 persen dari jumlah partikel yang terbang dan memiliki ukuran sampai 45 $\mu \mathrm{m} \quad$ (total suspendedparticulate) (Organization, 2013).

Jenis polutan udara yang sangat berbahaya bagi kesehatan manusia adalah partikulat. Partikulat menjadi membahayakan bagi kesehatan makhluk hidup apabila berada pada ukuran yang sangat tinggi di daerah tertentu. Penurunan kualitas udara akibat beredarnya partikulat telah banyak dihubungkan dengan peningkatan kasus kematian dan gejala penyakit. Jenis partikulat 
yang paling banyak diteliti dan dilihat karena bentuknya yang dapat menancap ke bagian dalam paru dan kandungannya yang dapat beredar dalam aliran darah adalah $\mathrm{PM}_{10}$ (Partikulat berukuran $\leq 10 \mu \mathrm{m}$ ) (Ratnani et al., 2013).

Partikulat debu diperoleh dari emisi partrikulat buangan kendaraan bermotor. Sekitar 50 persen - 60 persen dari jumlah gas yang melayang merupakan debu berukuran 10 $\mu \mathrm{m}$ atau diketahui sebagai PM10. Debu PM10 sangatlah gampang terhirup dan masuk serta menancap ke bagian paru-paru dalam, sehingga PM10 dikatakan sebagai Respirable Particulate Matter (RPM) (Christina, 2016). Akibatnya dapat merusak sistem pernafasan di bagian atas dan bagian bawah (alveoli). Di alveoli terjadi penggumpalan partikelukuran kecil yang mengakibatkan dapat mengganggu sistem jaringan paru-paru, sedangkan pada debu yang lebih kecil dari $10 \mu \mathrm{m}$, dapat mengakibatkan mata menjadi iritasi, merusak dan menghalangi penglihatan mata (Chahaya, 2015).

Dikeadaan tertentu, debu sangat berbahaya dan dapat menyebabkan gangguan kesehatan dan penurunan totalitas kinerja, gangguan fungsi faal paru, gangguan fungsi penglihatan bahkan sampai pada keracunan umum. Debu juga bias membentuk kerusakan di paru-paru dan fibrosis kalau terinhalasi selama terus menjalankan pekerjaan secara berulang kali. Bila alveoli keras dapat mengurangi elastisitas menampung jumlah udarasehingga kemampuan untuk mengikat oksigen lemah. Lingkungan kerja seringkali ditemukan uap, gas, debu dan lainnya yang dapat mengganggu peningkatan kinerja dan mengganggu kesehatan Hal ini dapat mengakibatkan pernapasan terganggu ataupun fungsi paru terganggu (Suma'mur, 2015).

Gangguan fungsi pada paru di kapasitas vital paksa atau forced vitalcapacity (FVC) dan jumlah penghirupan paksa dalam 1 detik atau forced expiratory volume in $1 \mathrm{~s}$
(FEV1), perhitungan kuantitatif pernafasan bagi kesehatan biasanya diteliti secara obyektif. Hal itu diperuntukkan untuk indikator dini peradangan pada kesehatan pernafasan dan yang terkait pada morbiditas dan mortalitas kardio respirasi (De Marco et al., 2000).

\section{Metode Penelitian}

Penelitian ini merupakan jenis penelitian observasional analitik dengan rancangan cross sectional. Penelitian ini dilakukan pada bulan Maret sampai April 2020. Populasi seluruh petugas parkir di Kota Medan. Jumlah sampel dalam penelitian ini sebanyak 30 orang diambil dari jalan HM.Yamin-Sutomo dan MT. Haryono Medan.

Pengumpulan data umur, lama bekerja dan masa bekerja menggunakan kuesioner, data penggunaan APD menggunakan kuesioner tentang APD (Alat Pelindung Diri) dan data gangguan fungsi paru menggunakan alat ukur Spirometer.

Data dianalisis secara deskriptif pada masing-masing variabel yang diteliti. Analisis inferensial dilakukan dengan uji Chi-Square untuk mengetahui hubungan kemaknaan antara variabel bebas dan terikat.

\section{Hasil dan Pembahasan}

\section{A. Hasil Penelitian}

Tabel 1

Karakteristik Responden dan gangguan Fungsi paru

\begin{tabular}{|c|c|c|}
\hline $\begin{array}{l}\text { Karakteristik } \\
\text { Responden }\end{array}$ & $\begin{array}{c}\text { Jumlah } \\
\text { (n) }\end{array}$ & $\begin{array}{c}\text { Persentase } \\
(\%)\end{array}$ \\
\hline \multicolumn{3}{|l|}{$\begin{array}{l}\text { Umur } \\
\text { Responden }\end{array}$} \\
\hline $18-34$ & 17 & 56,7 \\
\hline $35-50$ & 13 & 43,3 \\
\hline \multicolumn{3}{|l|}{ Masa Kerja } \\
\hline$<5$ tahun & 11 & 36,7 \\
\hline$\geq 5$ tahun & 19 & 63,3 \\
\hline \multicolumn{3}{|l|}{ Lama Kerja } \\
\hline$\leq 8 \mathrm{jam} / \mathrm{hari}$ & 14 & 46,7 \\
\hline$>8$ jam/hari & 16 & 53,3 \\
\hline
\end{tabular}




\begin{tabular}{lll}
\hline Ya & 10 & 33,3 \\
\hline Tidak & 20 & 66,7 \\
\hline $\begin{array}{l}\text { Gangguan } \\
\text { Fungsi Paru }\end{array}$ & & \\
\hline Ya & 17 & 56,7 \\
\hline Tidak & 13 & 43,3 \\
\hline
\end{tabular}

Berdasarkan tabel 1 diketahui bahwa pekerja yang berumur 18-34 yaitu sebanyak 17 orang 56,7(\%), sedangkan pekerja yang berumur dari 35-50 tahun berjumlah 13 orang $(43,3 \%)$. Pada masa kerja diketahui bahwa pekerja yang bekerja kurang dari lima tahun yaitu sebanyak 11 orang $(36,7 \%)$, sedangkan pekerja yang bekerja lebih atau sama dengan lima tahun sebanyak 19 orang $(63,3 \%)$. Pada lama kerja diketahui bahwa pekerja yang bekerja kurang dari 8 jam/hari sebanyak 14 orang $(46,7 \%)$ sedangkan pekerja yang bekerja lebih dari 8 jam/hari sebanyak 16 (53,3\%). Pada penggunaan APD (masker) diketahui bahwa pekerja yang menggunakan APD (masker) sebanyak 10 orang $(33,3 \%)$, sedangkan pekerja yang tidak menggunakan APD (masker) yaitu 20 orang (66,7\%). Pada Gangguan Fungsi paru diketahui bahwa pekerja yang terkena Fungsi Paru sebanyak 13 orang $(56,7 \%)$ sedangkan pekerja yang tidak terkena gangguan Fungsi paru sebanyak 13 orang $(43,3)$.

\section{Tabel 2}

Hubungan Umur dengan Gangguan Fungsi Paru

\begin{tabular}{|c|c|c|c|c|c|c|c|}
\hline \multirow{3}{*}{ Variabel } & \multicolumn{4}{|c|}{ Gangguan Fungsi Paru } & \multicolumn{2}{|c|}{$\underline{\text { Total }}$} & \multirow{3}{*}{$\begin{array}{c}p- \\
\text { value }\end{array}$} \\
\hline & \multicolumn{2}{|c|}{$\begin{array}{l}\begin{array}{l}\text { Ada } \\
\text { gangguan }\end{array} \\
\end{array}$} & \multicolumn{2}{|c|}{$\begin{array}{l}\text { Tidak ada } \\
\text { gangguan }\end{array}$} & $\mathbf{n}$ & $\%$ & \\
\hline & $\mathbf{N}$ & $\%$ & $\mathbf{n}$ & $\%$ & & & \\
\hline Umur & & & & & & & 0,001 \\
\hline $18-34$ & 14 & 78 & 4 & 22,2 & 17 & $\underline{10}$ & \\
\hline $35-50$ & 6 & 38 & 6 & 69,2 & 13 & $\overline{10}$ & \\
\hline
\end{tabular}

Berdasarkan tabel 2, Umur merupakan variabel independen yang ingin dianalisis hubungannya dengan variabel dependen yakni gangguan fungsi paru menunjukkan sebanyak 77,8 persen responden yang berumur 18-34. Hasil uji analisis bivariat menggunakan uji regresi logistik sederhana menunjukkan terdapat hubungan antara umur dan gangguan fungsi paru dimana p-value 0,001 .

Tabel 3 Hubungan Lama Bekerja dengan
Gangguan Fungsi Paru

\begin{tabular}{|c|c|c|c|c|}
\hline \multirow{3}{*}{ Variabel } & $\begin{array}{l}\text { Gangguan } \\
\text { Paru } \\
\end{array}$ & Fungsi & Total & \multirow{3}{*}{$\begin{array}{l}p- \\
\text { value }\end{array}$} \\
\hline & $\begin{array}{c}\text { Ada } \\
\text { ganggu } \\
\text { an } \\
\end{array}$ & $\begin{array}{c}\text { Tidak } \\
\text { ada } \\
\text { gangguan }\end{array}$ & $\%$ & \\
\hline & n $\%$ & n $\%$ & & \\
\hline Lama Kerja & & & & 0,696 \\
\hline$<8 \mathrm{jam} / \mathrm{hari}$ & $\begin{array}{ll}8 & 57,1 \\
\end{array}$ & $\begin{array}{ll}6 & 42,9 \\
\end{array}$ & $14 \quad 100$ & \\
\hline$>8 \mathrm{jam} / \mathrm{hari}$ & $\begin{array}{ll}8 & 50,0 \\
\end{array}$ & $8 \quad 50,0$ & $16 \quad 100$ & \\
\hline
\end{tabular}

Berdasarkan Berdasarkan Tabel 3, lama bekerja Lama kerja merupakan variabel independen yang ingin dianalisis hubungannya dengan variabel dependen yakni gangguan fungsi paru. menunjukkan sebanyak 57,1 persen responden yang bekerja selama $<8$ jam/hari mengalami gangguan fungsi paru. Hasil uji analisis bivariat menggunakan uji Chi-Square menunjukkan tidak terdapat hubungan dengan gangguan fungsi paru dimana $\mathrm{p}$ value 0,696

Tabel 4

\section{Hubungan Masa Bekerja dengan Gangguan Fungsi Paru}

\begin{tabular}{|c|c|c|c|c|c|c|c|}
\hline \multirow{3}{*}{ Variabel } & \multicolumn{4}{|c|}{$\begin{array}{c}\text { Gangguan Fungsi } \\
\text { Paru } \\
\end{array}$} & \multicolumn{2}{|c|}{ Total } & \multirow{3}{*}{$\begin{array}{c}p- \\
\text { value }\end{array}$} \\
\hline & \multicolumn{2}{|c|}{$\begin{array}{c}\text { Ada } \\
\text { gangguan }\end{array}$} & \multicolumn{2}{|c|}{$\begin{array}{c}\text { Tidak } \\
\text { ada } \\
\text { gangguan }\end{array}$} & \multirow[t]{2}{*}{$\mathbf{n}$} & \multirow[t]{2}{*}{$\%$} & \\
\hline & $\mathbf{n}$ & $\%$ & $\mathrm{n}$ & $\%$ & & & \\
\hline $\begin{array}{l}\text { Masa } \\
\text { kerja }\end{array}$ & & & & & & & 0,011 \\
\hline$<5$ tahun & 12 & 75,0 & 4 & 25,0 & 16 & 100 & \\
\hline$>5$ tahun & 4 & 28,6 & 10 & 71,4 & 14 & 100 & \\
\hline
\end{tabular}


Berdasarkan Tabel 4 Masa kerja merupakan variabel independen yang ingin dianalisis hubungannya dengan gangguan fungsi paru menunjukkan sebanyak 75,0 persen responden yang masa kerjanya $<5$ tahun. Hasil uji analisis bivariat menggunakan uji Chi-Square menunjukkan terdapat hubungan antara masa kerja dengan gangguan fungsi paru dimana p-value 0,011 .

Tabel 5

Hubungan penggunaan APD dengan Gangguan Fungsi Paru

\begin{tabular}{|c|c|c|c|c|c|c|}
\hline \multirow{3}{*}{ Variabel } & \multicolumn{3}{|c|}{$\begin{array}{c}\text { Gangguan Fungsi } \\
\text { Paru }\end{array}$} & \multicolumn{2}{|c|}{ Total } & \multirow[b]{2}{*}{$\begin{array}{c}p- \\
\text { value }\end{array}$} \\
\hline & & gguan & $\begin{array}{l}\text { Tidak } \\
\text { ada } \\
\text { gangguan }\end{array}$ & $\mathbf{n}$ & $\%$ & \\
\hline & $\mathbf{n}$ & $\%$ & $\underline{\mathrm{n}} \%$ & & & \\
\hline APD & & & & & & 0,010 \\
\hline $\mathrm{Ya}$ & 11 & 78,6 & 21,4 & 14 & 100 & \\
\hline Tidak & 5 & $\underline{31,2}$ & $\underline{11} \underline{68,8}$ & 16 & 100 & \\
\hline
\end{tabular}

Berdasarkan Tabel 5 APD (Alat Pelindung Diri) merupakan variabel independen yang ingin dianalisis hubungannya dengan variabel dependen yakni gangguan fungsi paru. menunjukkan sebanyak 78,6 persen responden yang menggunakan APD mengalami gangguan fungsi paru. Hasil uji analisis bivariat menggunakan uji Chi-Square menunjukkan tidak terdapat hubungan APD dengan gangguan fungsi paru dimana p-value 0,010 .

\section{B. Pembahasan}

\section{Hubungan Umur dengan Gangguan Fungsi Paru}

Berdasarkan hasil penelitian terdapat hubungan umur dengan gangguan fungsi paru didapatkan nilai $\mathrm{p}=0,001$ yang menyatakan bahwa terdapat hubungan umur dengan gangguan fungsi paru.

Hasil penelitian ini sejalan dengan penelitian (Nugroho, 2010), meskipun fungsi paru menurun selaras dengan bertambahnya usia, hal tersebut tidak pernah berhubungan langsung dengan kejadian kelainan fungsi paru.

\section{Hubungan Lama Bekerja dengan Gangguan Fungsi Paru}

Berdasarkan hasil penelitian tidak terdapat hubungan lama bekerja dengan gangguan fungsi paru didapatkan nilai $\mathrm{p}=0,696$ yang menyatakan bahwa tidak terdapat hubungan lama bekerja dengan gangguan fungsi paru.

Hasil penelitian ini sejalan dengan penelitian (Suma'mur, 2009) yang menyatakan lama paparan berpengaruh negatif bagi seseorang yang bekerja karena semakin lama terpapar, bahaya yang ditimbulkan oleh tempat kerja dapat mempengaruhi kesehatan terutama saluran pernapasan, menyatakan bahwa semakin lama seseorang terpapar debu maka semakin besar kemungkinan untuk terjadi gangguan kapasitas paru.

Hasil Penelitian ini tidak sejalan dengan penelitian (Ombuh et al., 2017), dimana responden yang bekerja lebih dari delapan jam sebanyak 28 responden, responden tersebut mengalami gangguan fungsi paru dan $20(71,4 \%)$ responden tidak mengalami gangguan fungsi paru. Sedangkan responden yang bekerja dibawah atau sama dengan delapan jam berjumlah 32 responden, $11 \quad(34 \%)$ mengalami gangguan fungsi paru sehingga didapatkan hasil nilai $\mathrm{p}=0,838$ ( $\mathrm{p}>0,05)$ maka tidak ada hubungan bermakna antara lama kerja dengan gangguan fungsi paru

\section{Hubungan Masa Bekerja dengan gangguan Fungsi Paru}

Berdasarkan hasil penelitian terdapat hubungan Masa Bekerja dengan gangguan fungsi paru didapatkan nilai $\mathrm{p}=0,011$ yang menyatakan bahwa terdapat hubungan masa bekerja dengan gangguan fungsi paru. 
Hasil penelitian ini Penelitian ini sejalan dengan penelitian (Sari et al., 2017), bahwa pekerja dengan masa kerja lebih atau sama dengan 10 tahun mengalami gangguan fungsi paru sebesar 70,8 persen. Hal ini dikarenakan pneumoconiosis akibat debu akan timbul setelah penderita mengalami kontak lama dengna debu. Jarang ditemui kelainan fungsi paru bila pajanan kurang dari 10 tahun.Dengan demikian lama pajanan atau lamanya masa kerja mempunyai pengaruh besar terhadap kejadian gangguan fungsi paru.

\section{Hubungan APD dengan Gangguan Fungsi Paru}

Berdasarkan hasil penelitian terdapat hubungan APD dengan gangguan fungsi paru didapatkan nilai $\mathrm{p}=0,010$ yang menyatakan bahwa terdapat hubungan APD dengan gangguan fungsi paru.

Hasil penelitian ini sejalan dengan penelitian (Purnomo \& Anwar, 2015) dari hasil uji statistik diperoleh nilai $\mathrm{p}=0,028$ sehingga dapat disimpulkan bahwa taraf kepercayaan $95 \%$ terdapat hubungan antara penggunaan APD dengan gejala penyakit saluran pernafasan. Nilai OR adalah 3,45 hal ini berarti pekerja meubel yang tidak menggunakan APD mempunyai peluang 3,45 kali mengalami gejala penyakit saluran pernafasan dibandingkan pekerja yang menggunakan APD (masker).

\section{Kesimpulan}

Penelitian ini menyimpulkan bahwa Pertama sebanyak $60 \%$ pekerja mengalami gangguan fungsi paru dan sebanyak $40 \%$ tidak mengalami gangguan fungsi paru. Kedua ada hubungan umur $(\mathrm{p}=0,001)$, masa bekerja $(\mathrm{p}=0,011)$ dan Ada hubungan penggunaan APD dengan gangguan fungsi paru $(\mathrm{p}=0,010)$. Ketiga tidak ada hubungan Lama Bekerja dengan gangguan fungsi paru $(\mathrm{p}=0,696)$.

\section{BIBLIOGRAFI}

Chahaya, I. (2003). Pemberantasan Vektor Demam Berdarah Di Indonesia. In Fakultas Kesehatan Masyarakat Universitas Sumatera Utara. Medan.

Christina, Y. M. (2016). Hubungan Konsentrasi Pm10 Dan Karakteristik Pekerja Terhadap Keluhan Subjektif Gangguan Pernapasan Akut Pada Petugas Di Area Basement Parkir Mal Blok M Dan Poins Square Tahun 2016. Uin Syarif Hidayatullah Jakarta: Fakultas Kedokteran Dan Ilmu Kesehatan, 2017.

De Marco, R., Locatelli, F., Sunyer, J., Burney, P., \& Group, E. C. R. H. S. S. (2000). Differences In Incidence Of Reported Asthma Related To Age In Men And Women: A Retrospective Analysis Of The Data Of The European Respiratory Health Survey. American Journal Of Respiratory And Critical Care Medicine, 162(1), 68-74.

Nugroho, A. (2010). Rekayasa Perangkat Lunak Berorientasi Objek Dengan Metode Usdp. Penerbit Andi.

Ombuh, R. V., Nurjazuli, N., \& Raharjo, M. (2017). Hubungan Paparan Debu Terhirup Terhadap Gangguan Fungsi Paru Pada Pekerja Bongkar Muat Di Pelabuhan Manado Sulawesi Utara Tahun 2017. Higiene: Jurnal Kesehatan Lingkungan, 3(2), 69-75.

Organization, W. H. (2013). Global Tuberculosis Report 2013. World Health Organization.

Pratomo, S. A. (2019). Penentuan Kadar Sulfur Dioksida (So2), Nitrogen Dioksida (No2), Oksidan (O3) Dan Amonia (Nh3) Udara Ambien Di Balai Hiperkes Dan Keselamatan Kerja Yogyakarta. Universitas Islam Indonesia. 
Faktor-Faktor yang Memengaruhi Gangguan Fungsi Paru pada Petugas Parkir di Kota Medan

Purba, L. S. L. (2020). The Effectiveness Of The Quizizz Interactive Quiz Media As An Online Learning Evaluation Of Physics Chemistry 1 To Improve Student Learning Outcomes. Journal Of Physics: Conference Series, 1567(2), 22039.

Purnomo, A., \& Anwar, T. (2015). Pajanan Debu Kayu (Pm10) Terhadap Gejala Penyakit Saluran Pernafasan Pada Pekerja Meubel Sektor Informal. Jurnal Vokasi Kesehatan, 1(6), 181-187.

Qadri, U., Wahyuni, R., \& Listiyawati, L. (2020). Inovasi Manajemen Pengelolaan Sampah Yang Berwawasan Lingkungan Di Kota Pontianak Berbasis Aplikasi. Eksos, 16(2), 144-160.

Ratnani, R. D., Budihardjo, A., \& Wikanta, D. K. (2013). Pengembangan Produksi Bioplastik Untuk Kerajianan Asesoris Dari Gliserol Sebagai Pemanfaatan Limbah Industri Biodisel. Laporan Penelitian Dan Pengabdian Masyarakat.

Sari, S., Anjani, R., Farida, I., \& Ramdhani, M. A. (2017). Using Android-Based Educational Game For Learning Colloid Material. Journal of Physics: Conference Series, 895(1), 12012.
Sinolungan, J. (2009). Dampak Polusi Partikel Debu Dan Gas Kendaraan Bermotor Pada Volume Dan Kapasitas Paru. Jurnal Biomedik: Jbm, I(2).

Suma'mur, P. K. (2009). Corporate Hygiene And Occupational Health. In Jakarta: Cv Sagung Seto.

Sumampouw, O. J. (2019). Perubahan Iklim Dan Kesehatan Masyarakat. Deepublish. 